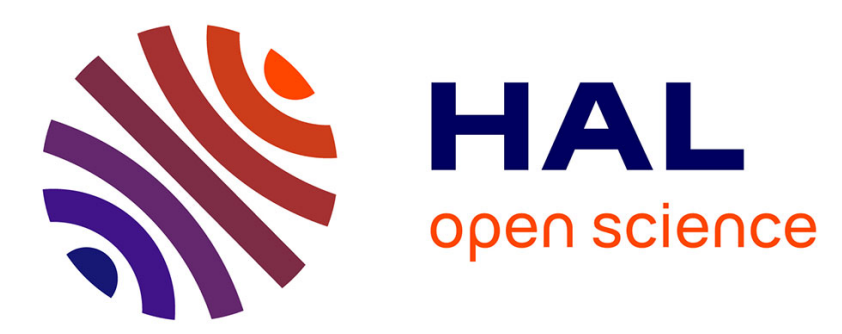

\title{
Highly Enantioselective Synthesis of $\beta$-Amino Alcohols
} Thomas-Xavier Métro, Jérôme Appenzeller, Domingo Gomez Pardo, Janine Cossy

\section{To cite this version:}

Thomas-Xavier Métro, Jérôme Appenzeller, Domingo Gomez Pardo, Janine Cossy. Highly Enantioselective Synthesis of $\beta$-Amino Alcohols. Organic Letters, 2006, 8, pp.3509 - 3512. 10.1021/ol061133d . hal-03230701

\section{HAL Id: hal-03230701 https://hal.science/hal-03230701}

Submitted on 21 May 2021

HAL is a multi-disciplinary open access archive for the deposit and dissemination of scientific research documents, whether they are published or not. The documents may come from teaching and research institutions in France or abroad, or from public or private research centers.
L'archive ouverte pluridisciplinaire HAL, est destinée au dépôt et à la diffusion de documents scientifiques de niveau recherche, publiés ou non, émanant des établissements d'enseignement et de recherche français ou étrangers, des laboratoires publics ou privés. 


\title{
Highly Enantioselective Synthesis of $\beta$-Amino Alcohols
}

\author{
Thomas-Xavier Métro, Jérôme Appenzeller, Domingo Gomez Pardo, ${ }^{\star}$ and \\ Janine Cossy*
}

Laboratoire de Chimie Organique, associé au CNRS, Ecole Supérieure de Physique et de Chimie Industrielles de la Ville de Paris (ESPCI), 10 rue Vauquelin, 75231 Paris Cedex 05, France

domingo.gomez-pardo@espci.fr; janine.cossy@espci.fr

Received May 9, 2006

\section{ABSTRACT}

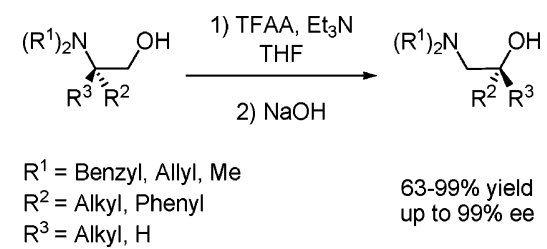

$\boldsymbol{N}, \boldsymbol{N}$-Dialkyl- $\beta$-amino alcohols derived from $\alpha$-amino acids can be rearranged enantiospecifically by using $\mathrm{TFAA}^{-\mathrm{Et}} \mathrm{t}_{3} \mathrm{~N} / \mathrm{NaOH}$ to give $1,2-a m i n o$ alcohols with enantiomeric excess up to $99 \%$.

$\beta$-Amino alcohol moieties are present in a large variety of naturally occurring and pharmacologically active molecules. ${ }^{1}$ The amino alcohol relative stereochemistry is highly important for the biological activity of these molecules. These entities can also be used as chiral auxiliaries in asymmetric synthesis. ${ }^{2,3}$

Linear $N, N$-dialkyl- $\beta$-amino alcohols have been shown to rearrange, via an aziridinium ion, into $\beta$-halogenoamines (on treatment with $\mathrm{SOCl}_{2},{ }^{4} \mathrm{MsCl},{ }^{5} \mathrm{TsCl},{ }^{5} \mathrm{SOBr}_{2},{ }^{6} \mathrm{CBr}_{4} / \mathrm{PPh}_{3},{ }^{7}$ DAST $^{8}$ or Deoxofluor ${ }^{9}$ ), into $\beta$-mesylamines (on treatment with $\mathrm{Ms}_{2} \mathrm{O}^{10,11}$ ), and into thiocyanates (on treatment with

(1) Bergmeier, S. C. Tetrahedron 2000, 56, 2561-2576 and references therein. 875.

(2) Ager, D. J.; Prakash, I.; Schaad, D. R. Chem. Rev. 1996, 96, 835-

(3) For recent examples of stereoselective synthesis of enantiopure $\beta$-amino alcohols see: (a) Keinicke, L.; Fristrup, P.; Norrby, P.-O.; Madsen, R. J. Am. Chem. Soc. 2005, 127, 15756-15761. (b) Cooper, T. S.; Larigo, A. S.; Laurent, P.; Moody, C. J.; Takle, A. K. Org. Biomol. Chem. 2005, $3,1252-1262$.

(4) (a) Back, T. G.; Parvez, M.; Zhai, H. J. Org. Chem. 2003, 68, 93899393. (b) Couty, F.; Durrat, F.; Prim, D. Tetrahedron Lett. 2004, 45, 3725-

3728. (c) Sivaprakasam, M.; Couty, F.; Evano, G.; Srinivas, B.; Sridhar, R.; Rama Rao, K. Synlett 2006, 5, 781-785.

(5) Weber, K.; Kuklinski, S.; Gmeiner, P. Org. Lett. 2000, 2, 647-649 and references therein.

(6) Nagle, A. S.; Salvatore, R. N.; Chong, B.-D.; Jung, K. W. Tetrahedron Lett. 2000, 41, 3011-3014.

(7) Lehmann, T.; Hübner, H.; Gmeiner, P. Bioorg. Med. Chem. Lett. 2001, 11, 2863-2866.
$\mathrm{KSCN}^{12}$ ). Recently we have shown that prolinols can be rearranged enantiospecifically to give optically active piperidin-3-ols, via an aziridinium intermediate, by using TFAA/ $\mathrm{Et}_{3} \mathrm{~N} / \mathrm{NaOH} .^{13,14}$ In this Letter, we would like to report that these latter conditions can be applied to linear optically active $\beta$-amino alcohols of type $\mathbf{A}$ to produce 1,2-amino alcohols of type $\mathbf{B}$ in a very regio-, stereo-, and enantioselective process (Scheme 1).

$N, N$-Dibenzyl- $\beta$-amino alcohols $\mathbf{2 a},{ }^{15} \mathbf{2 c},{ }^{5} \mathbf{2 e},{ }^{16} \mathbf{2 f},{ }^{17} \mathbf{2 g}$, and $2 \mathbf{h}^{18}$ were prepared from the commercially available amino alcohols by using benzyl bromide ( 2.2 equiv) in the

(8) Hook, D. F.; Gessier, F.; Noti, C.; Kast, P.; Seebach, D. ChemBioChem 2004, 5, 691-706.

(9) Ye, C.; Shreeve, J. M. J. Fluorine Chem. 2004, 125, 1869-1872. 6776 .

(11) For an interesting example of the utilization of $\mathrm{Ms}_{2} \mathrm{O}$ in the formation of an aziridinium intermediate, see: Couturier, C.; Blanchet, J.; Schlama, T.; Zhu, J. Org. Lett. 2006, 8, 2183-2186.

(12) Anderson, J. C.; Cubbon, R.; Harding, M.; James, D. S. Tetrahedron: Asymmetry 1998, 9, 3461-3490.

(13) For comprehensive reviews, see: (a) Cossy, J.; Gomez Pardo, D Chemtracts 2002, 15, 579-605. (b) Cossy, J.; Gomez Pardo, D. Targets Heterocycl. Syst. 2002, 6, 1-26.

(14) (a) Cossy, J.; Dumas, C.; Gomez Pardo, D. Eur. J. Org. Chem. 1999, 1693-1699. (b) Brandi, A.; Cicchi, S.; Paschetta, V.; Gomez Pardo, D.; Cossy, J. Tetrahedron Lett. 2002, 43, 9357-9359. (c) Déchamps, I.; Gomez Pardo, D.; Karoyan, P.; Cossy, J. Synlett 2005, 1170-1172. (d) Roudeau, R.; Gomez Pardo, D.; Cossy, J. Tetrahedron 2006, 62, 23882394 and references therein. 


\section{Scheme 1}

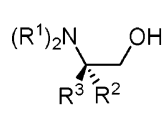

1) $\mathrm{TFAA}, \mathrm{Et}_{3} \mathrm{~N}$

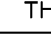

2) $\mathrm{NaOH}$

$\mathrm{R}^{1}=$ Benzyl, Allyl, Me

$\mathrm{R}^{2}=$ Alkyl, Pheny

$\mathrm{R}^{3}=$ Alkyl, $\mathrm{H}$

presence of $\mathrm{K}_{2} \mathrm{CO}_{3}$ (3 equiv) and $n$-tetrabutylammonium iodide ( 0.3 equiv) in refluxing acetonitrile (Table 1$) . \mathrm{N}, \mathrm{N}$ Dibenzyl- $\beta$-amino alcohols $\mathbf{2 b}$ and $\mathbf{2 d}$ are commercially available.

Table 1. Synthesis of $N, N$-Dibenzylamino Alcohols
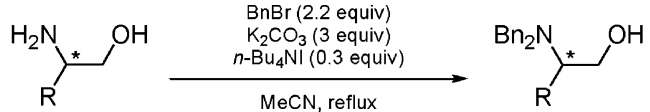

1a-h

2a-h

\begin{tabular}{cccc}
\hline entry & $\mathrm{R}$ \\
\hline 1 & $\mathrm{Ph}$ \\
\hline
\end{tabular}

product (yield)

2a $(79 \%)$

2c $(76 \%)$

2 e $(81 \%)$

$2 \mathbf{f}(75 \%)$

$2 \mathrm{~g}(67 \%)$

2h $(96 \%)$

The optically active amino alcohol $(R)$-2i was synthesized from the racemic phenylglycine 3. Esterification with $\mathrm{SOCl}_{2}$ in ethanol followed by treatment with benzaldehyde furnished the corresponding imine 4. After alkylation under catalytic phase transfer conditions (AllylBr, $n$ - $\mathrm{Bu}_{4} \mathrm{NHSO}_{4}, \mathrm{NaOH}$, $\mathrm{CH}_{2} \mathrm{Cl}_{2}$ ) and hydrolysis of the imino group, the racemic amino ester $\mathbf{5}$ was obtained in $75 \%$ yield. The resulting $\alpha$-allylphenylglycine ethyl ester $\mathbf{5}$ was subjected to a kinetic enzymatic resolution by using lipase $\mathrm{PLE}^{19}$ to provide the $(R)$-enantiomer of $\mathbf{5}$ in $45 \%$ yield and $91 \%$ enantiomeric excess. $^{20,21}$ This latter compound was then converted to the corresponding amino alcohol $(R)-\mathbf{2} \mathbf{i}$ in $57 \%$ yield by reduction with $\mathrm{LiAlH}_{4}$, followed by bis- $N$-benzylation with benzyl

(15) Cepanec, I.; Litvić, M.; Mikuldaš, H.; Bartolinčić, A.; Vinković V. Tetrahedron 2003, 59, 2435-2439.

(16) Ma, D.; Xie, W.; Zou, B.; Lei, Q.; Pei, D. Tetrahedron Lett. 2004 $45,8103-8105$

(17) Brunin, T.; Cabou, J.; Bastin, S.; Brocard, J.; Pélinski, L. Tetrahedron: Asymmetry 2002, 13, 1241-1243.

(18) Rozwadowska, M. D. Tetrahedron 1997, 53, 10615-10622.

(19) Lipase PLE was purchased from Sigma. bromide $\left(\mathrm{K}_{2} \mathrm{CO}_{3}, n\right.$ - $\mathrm{Bu}_{4} \mathrm{NI}, \mathrm{CH}_{3} \mathrm{CN}$, microwaves irradiation, $120{ }^{\circ} \mathrm{C}, 3 \mathrm{~h}$ ) (Scheme 2).

Scheme 2

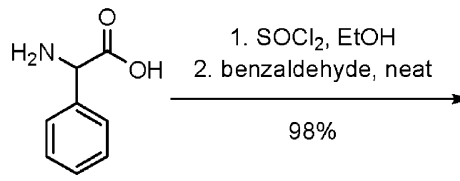

3

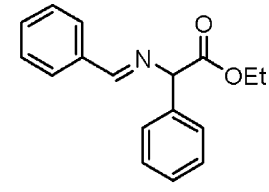

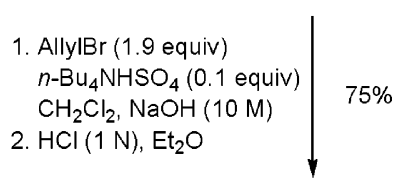
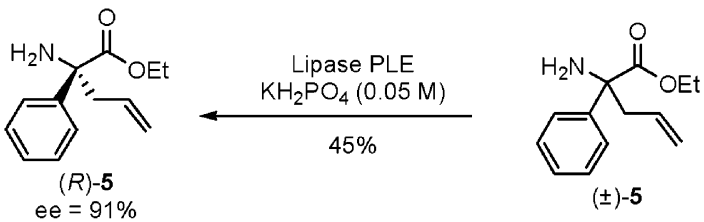

$( \pm)-5$

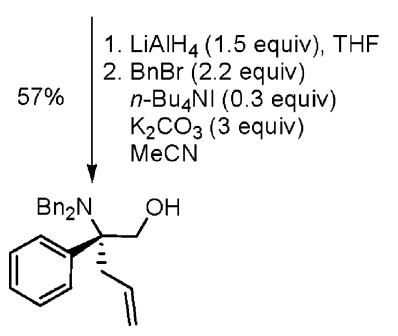

$(R)-2 \mathbf{i}$

$N, N$-Dibenzylamino alcohols $\mathbf{2 a}-\mathbf{i}$ were treated with trifluoroacetic anhydride (TFAA, 1.5 equiv) and $\mathrm{Et}_{3} \mathrm{~N}$ (2 equiv) and heated at $100{ }^{\circ} \mathrm{C}$ under microwave (MW) irradiation. After $2 \mathrm{~h}$, the reaction mixture was treated with $\mathrm{NaOH}(3.75 \mathrm{~N})$ to provide the $N, N$-dibenzyl- $\beta$-amino alcohols $6 \mathbf{a}-\mathbf{i}$ in good yields and with excellent enantiomeric excess (Table 2). ${ }^{22}$ The $(S)$-absolute configuration of $\mathbf{6 a}^{23}$ was determined by comparison of the $[\alpha]_{\mathrm{D}}$ of the $(S)-N, N$ 2-dibenzylamino-1-phenylethanol synthesized from the commercially available $(S)$-2-amino-1-phenylethanol. The $(R)$ absolute configuration was established for compounds $\mathbf{6 b},{ }^{24}$ $\mathbf{6 d},{ }^{24}$ and $6 \mathbf{e}^{25}$ by comparison of the $[\alpha]_{D}$ reported in the literature. We have to point out that in the case of amino1,3-diol $\mathbf{2 h}$ the amino-1,2-diol $\mathbf{6 h}$ was obtained in $66 \%$ yield indicating that the reaction is very regio- and diastereoselective. Furthermore, almost no loss of chirality was observed in the case of the amino alcohol $\mathbf{6 i}$, possessing a tertiary hydroxyl group, as it was obtained from $2 \mathbf{i}$ with $63 \%$ yield

(20) Betsbrugge, J. V.; Tourwé, D.; Kaptein, B.; Kierkels, H.; Broxterman, R. Tetrahedron 1997, 53, 9233-9240.

(21) Determined by chiral HPLC, using a Chiralpack AD-H column

(22) Similar yield and ee were obtained when heating $\mathbf{2 b}$ in a sealed tube at $100{ }^{\circ} \mathrm{C}$ for $2 \mathrm{~h}$.

(23) Shibata, T.; Takahashi, T.; Konishi, T.; Soai, K. Angew. Chem., Int. Ed. Engl. 1997, 36, 2458-2460.

(24) Schwerdtfeger, J.; Kolczewski, S.; Weber, B.; Fröhlich, R.; Hoppe, D. Synthesis 1999, 9, 1573-1592.

(25) Koppenhoefer, B.; Trettin, U.; Wächtler, A. Synthesis 1994, 12 , $1141-1142$. 
Table 2. Rearrangement of $N, N$-Dibenzylamino Alcohols

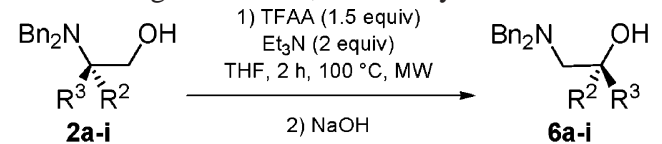

2) $\mathrm{NaOH}$

6a-i

(2)

${ }^{a}$ Determined by chiral HPLC (see the Supporting Information for details). ${ }^{b}$ Determined by application of the modified Mosher method. ${ }^{26}{ }^{c}$ TFAA ( 4,5 equiv), $\mathrm{Et}_{3} \mathrm{~N}$ (9 equiv), reflux, $37 \mathrm{~h} .{ }^{d}$ TFAA ( 3 equiv), $\mathrm{Et}_{3} \mathrm{~N}$ (4 equiv). ${ }^{e}$ TFAA (1,1 equiv), $\mathrm{Et}_{3} \mathrm{~N}$ (1,5 equiv). ${ }^{f}$ TFAA ( 2 equiv), $\mathrm{Et}_{3} \mathrm{~N}$ ( 3 equiv), $\mathrm{rt}, 48 \mathrm{~h}$.

and $88 \%$ ee [starting from ee (2i) 91\%]. Even for amino alcohols of type $\mathbf{A}$ possessing a quaternary center, the rearrangement is enantiospecific as compounds of type $\mathbf{B}$ were obtained with good enantiomeric excess.

$N$-Alkyl groups have almost no influence on the rearrangement, as the $N, N$-diallylamino alcohol $7 \mathbf{a}^{27}$ and the $N, N$ -

(26) Seco, J. M.; Quiñoá, E.; Riguera, R. Tetrahedron: Asymmetry 2001, $12,2915-2925$.

(27) Fiaux, H.; Popowycz, F.; Favre, S.; Schütz, C.; Vogel, P.; GerberLemaire, S.; Juillerat-Jeanneret, L. J. Med. Chem. 2005, 48, 4237-4246. dimethylamino alcohol $\mathbf{7} \mathbf{b}^{28}$ led to the amino alcohols $\mathbf{8} \mathbf{a}^{29}$ and $\mathbf{8 b ^ { 3 0 }}$ in $85 \%$ and $72 \%$ yield, and in $99 \%$ and $95 \%$ enantiomeric excess, respectively (Table 3 ). The $(S)$-configuration of $\mathbf{8 a}$ and $\mathbf{8 b}$ were established by comparison with the $[\alpha]_{D}$ reported in the literature..$^{29,30}$

Table 3. Rearrangement of Diallyl- and Dimethylamino Alcohols

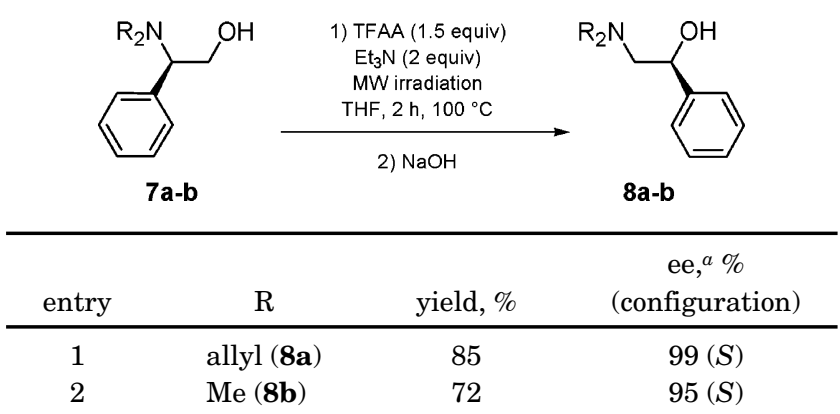

${ }^{a}$ Determined by chiral HPLC (see the Supporting Information for details)

The stereospecificity of this reaction can be rationalized by the intermediacy of an aziridinium ion of type E. ${ }^{13}$ This aziridinium is formed from the ammonium trifluoroacetate ester $\mathbf{C}$, which is transformed to the aziridinium $\mathbf{E}$, via the amino ester $\mathbf{D}$, after treatment with $\mathrm{Et}_{3} \mathrm{~N}$. As a trifluoroacetate anion is liberated into the reaction media, this anion can attack the more substituted carbon atom of the aziridinium $\mathbf{E}$, producing the aminoester $\mathbf{F}$. By analogy with the work of Gmeiner, ${ }^{10}$ we assume that compounds $\mathbf{D}$ and $\mathbf{F}$ are in equilibrium, and that the secondary trifluoroacetate ester $\mathbf{F}$ is the thermodynamic product. After saponification of $\mathbf{F}$, amino alcohols of type $\mathbf{B}$ are liberated (Scheme 3 ). Due to the high ee observed in the rearrangement it is unlikely that the reaction proceeds via a planar carbocation intermediate.

Scheme 3
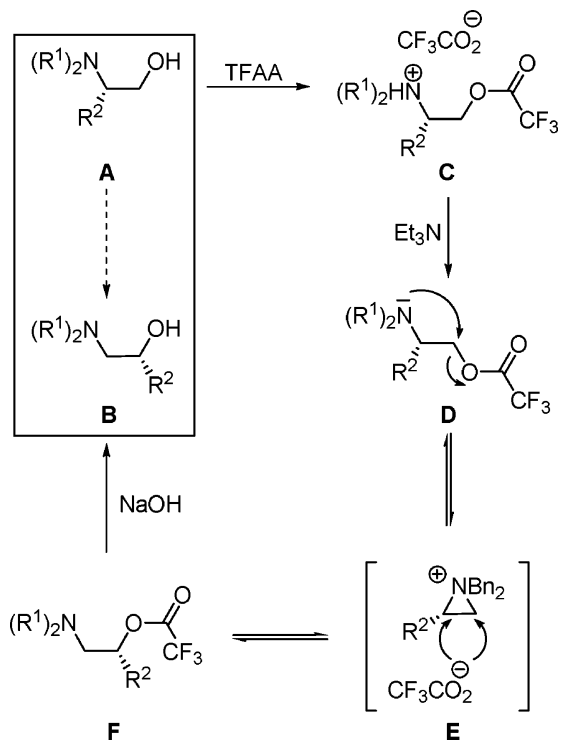

E 
The treatment of 1,2-amino alcohols with TFAA/Et $3 \mathrm{~N} /$ $\mathrm{NaOH}$ is a very powerful procedure that allows the synthesis of $\beta$-amino alcohols of type $\mathbf{B}$ with high yield and enantiomeric excess. Furthermore, the $N, N$-dibenzyl- $\beta$-amino alcohols of type $\mathbf{B}$ can be used to provide chiral 2-amino-1-alkylethanols by hydrogenolysis of benzyl groups. ${ }^{25}$ Further

(28) Bernardi, L.; Bonini, B. F.; Comes-Franchini, M.; Fochi, M.; Mazzanti, G.; Ricci, A.; Varchi, G. Eur. J. Org. Chem. 2002, 16, $2776-$ 2784.

(29) Saravanan, P.; Bisai, A.; Baktharaman, S.; Chandrasekhar, M.; Singh, V. K. Tetrahedron 2002, 58, 4693-4706.

(30) Miyano, S.; Lu, L. D.-L.; Viti, S. M.; Sharpless, K. B. J. Org. Chem. $1985,50,4350-4360$. studies with amino alcohols of type $\mathbf{B}$ as chiral auxiliaries, as well as in the synthesis of natural products, are currently underway.

Acknowledgment. Sanofi-Aventis is greatly acknowledged for financial support (Grant to T.-X.M.)

Supporting Information Available: General experimental procedure and characterization data of compounds $\mathbf{2 a}$, $\mathbf{2 c}, \mathbf{2 e}-\mathbf{i}, \mathbf{6 a}-\mathbf{i}, 7 \mathbf{a}, \mathbf{b}$, and $\mathbf{8 a}, \mathbf{b}$. This material is available free of charge via the Internet at http://pubs.acs.org. 